\title{
Seroprevalence of Leptospira hardjo in Cattle of Gujarat, India
}

\author{
J.M. Patel $^{1}{ }^{*}$, M.C. Prasad ${ }^{1}$, P.D. Vihol ${ }^{1}$, I.H. Kalyani ${ }^{2}$, M.G. Prajapati ${ }^{3}$, \\ H.C. Parmar ${ }^{4}$, R.D. Varia ${ }^{5}$ and K.M. Patel $^{3}$ \\ ${ }^{1}$ Department of Veterinary Pathology, Gujarat, India \\ ${ }^{2}$ Department of Veterinary Microbiology, Gujarat, India \\ ${ }^{3}$ Department of Animal Husbandry, Gujarat State Government, Gujarat, India \\ ${ }^{4}$ Krishi Vigyan Kendra, Navsari Agricultural University, Surat \\ ${ }^{5}$ Department of Veterinary Pharmacology and Toxicology, Vanbandhu College of Veterinary \\ Science and Animal husbandry, Navsari Agricultural University, Navsari, Gujarat, India \\ *Corresponding author
}

\begin{tabular}{|c|c|}
\hline & A B S T R A C T \\
\hline Keywords & \multirow{4}{*}{$\begin{array}{l}\text { The aim of this study was to determine prevalence of Leptospira interrogans } \\
\text { serovar hardjo in the define area. To serve the purpose a total } 398 \text { serum samples } \\
\text { were collected from different age group, breed and sex of cattle. Out of 398, some } \\
\text { of cattle (101) showed history of abortion, mastitis/agalactia/oligolactia, repeat } \\
\text { breeder and fever. These samples were screened by I-ELISA kit which detect } \\
\text { antibody directed against } L \text {. hardjo. The distribution of serovar hardjo was } \\
\text { significantly differed between different districts (Navsari, Tapi, Valsad, Surat) of } \\
\text { South Gujarat. The highest seroprevalence of } L \text {. hardjo was found in Valsad } \\
\text { district }(21.56 \%) \text { followed by Surat }(6.89 \%) \text {, Tapi ( } 3.30 \%) \text { and Navsari ( } 3.04 \\
\%) \text {. However, there was statistically insignificant difference was observed in } \\
\text { distribution of serovar hardjo between different breeds, age and sex of cattle. }\end{array}$} \\
\hline $\begin{array}{l}\text { I-ELISA, } \\
\text { Leptospirosis, } \\
\text { L. hardjo, } \\
\text { Seroprevalence, } \\
\text { Weather data. }\end{array}$ & \\
\hline Article Info & \\
\hline $\begin{array}{l}\text { Accepted: } \\
\text { 12 September } 2017 \\
\text { Available Online: } \\
\text { 10 November } 2017\end{array}$ & \\
\hline
\end{tabular}

\section{Introduction}

Leptospirosis is a zoonotic bacterial disease with global distribution. It is caused by any one or more than one serovars of about 260 serovars belonging to 23 serogroups (serotypes) of pathogenic species Leptospira interrogans (Adler and Pena Moctezuma, 2010).

Globally a number of serovars are recognized but only a limited numbers are usually endemic to a particular region (Angeliki, 2010). Leptospira is associated with infertility, early embryonic death and agalactia/oligolactia/mastitis. Leptopsiral serovar hardjo, pomona and grippotyphosa are implicated in bovine abortion leads to heavy economic losses of dairy farmers.

Among different leptospiral serovar, hardjo serovar is considered the most frequent and important serovar (Radostits et al., 2007). So, in present study researcher aimed to know prevalence of this specific serovar in cattle of Gujarat, India. 


\section{Materials and Methods}

\section{Collection of blood/ serum samples}

A total of 398 blood/serum samples were collected randomly from clinically ailing (cattle $=101)$ and apparently healthy (cattle = 297) cattle of both sex reared in villages of various districts (Navsari, Surat, Tapi, Valsad) of South Gujarat. Whole blood samples were collected from jugular vein directly in sterile $9.0 \mathrm{ml}$ plain vacutainers. To obtain serum whole blood was kept in slanting position in $9.0 \mathrm{ml}$ plain vacutainers until serum was extracted out of the whole blood. The $9.0 \mathrm{ml}$ plain vacutainers were centrifuged at $7000 \mathrm{rpm}$ for 10 minutes. The clear straw coloured serum was collected into $1.5 \mathrm{ml}$ sterile cryo vials and kept at $-20^{\circ} \mathrm{C}$ until use.

\section{I-ELISA Test}

A commercial indirect ELISA kit (M/S: The Cypress, Ref.VB066/ 480 tests/kit) was used for detection of antibodies against Leptospira interrogans serovar hardjo (L. hardjo) in serum. Indirect Elisa was performed strictly as per the protocol outlined in the user's manual supplied with the kit. Then read the optical densities in the microwells using a micro plate reader at a wavelength of $450 \mathrm{~nm}$ within 15 minutes of stopping the colour development. ELISA optical density (OD) readings were transformed to serum/positive percentage (PP) according to specific equation cited by manufacture.

\section{Statistical analysis}

Chi-square test was used at $95 \%$ confidence interval according to WEB AGRI STAT PACKAGE software developed by Jangam and Wadekar, ICAR research complex, Goa for statistical analysis of data (Jangam and Wadekar, 2012).

\section{Results and Discussion}

In the present study, distribution of serovar hardjo between different districts of South Gujarat was statistically significant (Table 1). A total of 398 samples tested from South Gujarat, $23(5.77 \%)$ were found to be positive against hardjo specific antibody (Figure 1). In Valsad district seroprevalence of $L$. hardjo was found highest $(21.56 \%)$ followed by Surat $(6.89 \%)$, Tapi $(3.30 \%)$ and Navsari (3.04 \%). There was statistically insignificant difference was observed in distribution of serovar Hardjo between different breeds, age and sex of cattle (Table 2). Serovar hardjo infecting cattle shown history of abortion, mastitis/agalactia/ oligolactia, repeat breeder and fever (Table $3)$.

In the present study seroprevalence of serovar hardjo was found to be 5.77 per cent and supported the findings of Savalia, 2001and Balakrishnan et al., (2011) who too reported serovar hardjo was most prevalent in Gujarat. In the same line serovar hardjo also predominated in different states of India, such as Uttaranchal (Agrawal et al., 2005) and West Bengal (Mandal et al., 2008) among cattle. Moreover, in some of the countries also serovar hardjo was found to be most prevalent i.e. in Arizona, USA (Songer et al., 1983), Malaysia (Bahaman et al., 1987; El Jalii, 2008), Turkish (Kocabiyik and Cetin, 2004), Iraq (Al-Badrawi et al., 2010) and Brazil (Mineiro et al., 2011), however in few of the countries like in Mexico serovar tarassovi (Cárdenas-Marrufo et al., 2011) and in Iran serovar canicola (Bahari et al., 2011), ictrohaemorhagiae (Sakhaee et al., 2007) were most prevalent. So prevalence of leptopsiral serovars are varies from country to country and depends upon weather condition, rainfall, humidity, presence of carrier animals and soil components (Himani et al., 2013). Highest seroprevalence in Valsad attributed to 
location (temperate zone) of district and comparatively higher rainfall as compare to other district of South Gujarat (Table 4). In the present study we could not found significant difference in distribution of hardjo serovar in different exotic, indigenous and cross breed of cattle.
In the contrast to this Balakrishnan et al., (2011) noted that exotic pure breeds are more susceptible followed by indigenous pure breeds and cross breeds with different leptospiral serovar infection. Further, Agrawal et al., (2005) found hardjobovis serovar only in indigenous breeds of cattle.

Table.1 Seroprevalence of leptospirosis in different district of South Gujarat among cattle using ELISA

\begin{tabular}{|l|l|l|l|l|l|}
\hline \multirow{2}{*}{ Attributes } & \multicolumn{4}{|c|}{ Districts } & \multirow{2}{*}{ Total } \\
\cline { 2 - 5 } & \multicolumn{1}{|c|}{ Navsari } & \multicolumn{1}{|c|}{ Valsad } & \multicolumn{1}{|c|}{ Tapi } & \multicolumn{1}{c}{ Surat } & \\
\hline No. of Tested & 197 & 51 & 121 & 29 & 398 \\
\hline No. of Positive & 06 & 11 & 04 & 02 & 23 \\
\hline Percent Positive & 3.04 & 21.56 & 3.30 & 6.89 & 5.77 \\
\hline$\chi^{2}=7.82 *(P<0.05)$ &
\end{tabular}

Note: NS-Non significant at $\mathrm{P}<0.05^{*}-$ Significant at $\mathrm{P}<0.05$

Table.2 Seroprevalence of leptospirosis in different district, breed, sex and age of cattle

\begin{tabular}{|c|c|c|c|}
\hline Attributes & No. of Tested & No. of Positive & Percent Positive \\
\hline \multicolumn{4}{|l|}{ Districts } \\
\hline Navsari & 197 & 06 & 3.04 \\
\hline Valsad & 51 & 11 & 21.56 \\
\hline Tapi & 121 & 04 & 3.30 \\
\hline Surat & 29 & 02 & 6.89 \\
\hline Total & 398 & 23 & 5.77 \\
\hline \multicolumn{4}{|l|}{$\chi^{2}=7.82 *(\mathrm{P}<0.05)$} \\
\hline \multicolumn{4}{|l|}{ Breed wise } \\
\hline $\begin{array}{l}\text { Holstein } \\
\text { Friesian }\end{array}$ & 65 & 03 & 4.61 \\
\hline Jersey & 26 & 02 & 7.69 \\
\hline Gir & 36 & 03 & 8.33 \\
\hline HF Cross & 242 & 14 & 5.78 \\
\hline Jersey Cross & 16 & 01 & 6.25 \\
\hline Gir Cross & 13 & 00 & 00 \\
\hline Total & 398 & 23 & 5.77 \\
\hline \multicolumn{4}{|l|}{$\chi^{2}=11.07^{\mathrm{NS}}(\mathrm{P}<0.05)$} \\
\hline \multicolumn{4}{|l|}{ Sex wise } \\
\hline Male & 35 & 01 & 2.85 \\
\hline Female & 363 & 22 & 6.06 \\
\hline Total & 398 & 23 & 5.77 \\
\hline \multicolumn{4}{|l|}{$\chi^{2}=3.84^{\mathrm{NS}}(\mathrm{P}<0.05)$} \\
\hline \multicolumn{4}{|l|}{ Age wise } \\
\hline$<1$ year & 35 & 00 & 00.00 \\
\hline $1-4$ years & 124 & 08 & 6.45 \\
\hline$>4$ years & 239 & 15 & 6.27 \\
\hline Total & 398 & 23 & 5.77 \\
\hline$\chi^{2}=5.99^{\mathrm{NS}}(\mathrm{P}<0.05)$ & & & \\
\hline
\end{tabular}

Note: NS-Non significant at $\mathrm{P}<0.05^{*}-$ Significant at $\mathrm{P}<0.05$ 
Table.4 Monthly average of weather data of sample collection period from June, 2012 to May, 2013 of four districts (Navsari, Surat, Tapi and Valsad)

\begin{tabular}{|c|c|c|c|c|c|c|c|c|c|c|c|c|}
\hline & \multicolumn{3}{|c|}{ Navsari } & \multicolumn{3}{|c|}{ Surat } & \multicolumn{3}{|c|}{ Tapi } & \multicolumn{3}{|c|}{ Valsad } \\
\hline & $\begin{array}{l}\text { RH } \\
(\%)\end{array}$ & $\begin{array}{c}\text { Temp. } \\
\left({ }^{\circ} \mathrm{C}\right)\end{array}$ & $\begin{array}{c}\text { Rain } \\
\text { fall } \\
\text { (mm) }\end{array}$ & $\begin{array}{l}\text { RH } \\
(\%)\end{array}$ & $\begin{array}{c}\text { Temp. } \\
\left({ }^{\circ} \mathbf{C}\right)\end{array}$ & $\begin{array}{c}\text { Rain } \\
\text { fall } \\
(\mathbf{m m})\end{array}$ & $\begin{array}{l}\text { RH } \\
(\%)\end{array}$ & $\begin{array}{c}\text { Temp. } \\
\left({ }^{\circ} \mathbf{C}\right)\end{array}$ & $\begin{array}{c}\text { Rain } \\
\text { fall } \\
(\mathrm{mm})\end{array}$ & $\begin{array}{l}\text { RH } \\
(\%)\end{array}$ & $\begin{array}{c}\text { Temp. } \\
\left({ }^{\circ} \mathbf{C}\right)\end{array}$ & $\begin{array}{c}\text { Rain } \\
\text { fall } \\
(\mathbf{m m})\end{array}$ \\
\hline Jun-12 & 84.4 & 30.2 & 155.0 & 77.1 & 30.8 & 86.0 & 64.50 & 26.9 & 8.00 & 79.7 & 29.8 & 139.4 \\
\hline Jul-12 & 92.1 & 28.5 & 271.0 & 85.7 & 29.2 & 185.6 & 79.00 & 25.6 & 262 & 92.9 & 28.0 & 577.6 \\
\hline Aug-12 & 92.4 & 27.8 & 200.0 & 83.7 & 28.6 & 127.6 & 86.20 & 26.0 & 275 & 94.1 & 27.4 & 348.1 \\
\hline Sep-12 & 93.0 & 27.4 & 618.0 & 87.5 & 27.5 & 376.2 & 87.50 & 25.3 & 240 & 94.0 & 27.2 & 512.9 \\
\hline Oct-12 & 80.0 & 28.5 & 12.0 & 74.8 & 27.3 & 0.0 & 80.00 & 25.9 & 11.00 & 84.1 & 27.9 & 19.2 \\
\hline Nov-12 & 72.8 & 24.7 & 0.0 & 69.4 & 26.7 & 0.0 & 74.50 & 25.7 & 0.0 & 44.8 & 12.4 & 0.0 \\
\hline Dec-12 & 71.9 & 24.1 & 0.0 & 70.1 & 24.2 & 0.0 & 60.90 & 22.7 & 0.0 & 89.7 & 22.6 & 0.0 \\
\hline Jan-13 & 81.6 & 21.0 & 0.0 & 68.3 & 22.8 & 0.0 & 68.60 & 19.3 & 0.0 & 89.3 & 19.9 & 0.0 \\
\hline Feb-13 & 71.5 & 23.1 & 0.0 & 57.5 & 23.5 & 0.0 & 62.30 & 24.2 & 0.0 & 81.0 & 21.8 & 0.0 \\
\hline Mar-13 & 72.9 & 26.9 & 0.0 & 66.5 & 27.0 & 0.0 & 65.65 & 25.3 & 0.0 & 78.1 & 25.4 & 0.0 \\
\hline Apr-13 & 84.2 & 28.4 & 0.1 & 83.2 & 28.8 & 0.0 & 62.05 & 25.6 & 0.0 & 79.5 & 27.3 & 13.1 \\
\hline May-13 & 84.3 & 30.8 & 0.4 & 84.3 & 30.9 & 0.0 & 61.75 & 25.4 & 0.0 & 75.3 & 29.8 & 0.0 \\
\hline Average & 81.76 & 26.78 & 251.20 & 75.68 & 27.28 & 155.08 & 71.08 & 24.81 & 159.20 & 81.88 & 24.94 & 319.44 \\
\hline
\end{tabular}

RH*: Relative Humidity Temp**: Temperature 
Table.3 Prevalence of Leptospira serovar hardjo in clinically ailing and apparently healthy cattle

\begin{tabular}{|c|c|c|c|}
\hline Sr. No. & Particulars & Total cases & Seropositive cases \\
\hline \multirow[t]{6}{*}{1.} & Clinically ailing animals & 101 & $9(8.91 \%)$ \\
\hline & a. Mastitis/Agalactia/Oligolactia & 25 & $3(12.00 \%)$ \\
\hline & b. Abortion & 15 & $3(20.00 \%)$ \\
\hline & c. Repet breeder & 17 & $1(5.88 \%)$ \\
\hline & d. Fever & 27 & $2(7.40 \%)$ \\
\hline & e. Anorexia & 17 & 0 \\
\hline \multirow[t]{2}{*}{2.} & Apparently healthy & 297 & $14(4.71 \%)$ \\
\hline & Total (1.to 2.) & 398 & $23(5.77 \%)$ \\
\hline
\end{tabular}

Fig.1 ELISA module showing positive and negative reactions for Leptospira antibodies Well A1 as S : Substrate blank, Well B1 and B2 as NC: Negative control, Well C1 and C2 as PC :

Positive control, Rest all wells: Field serum samples

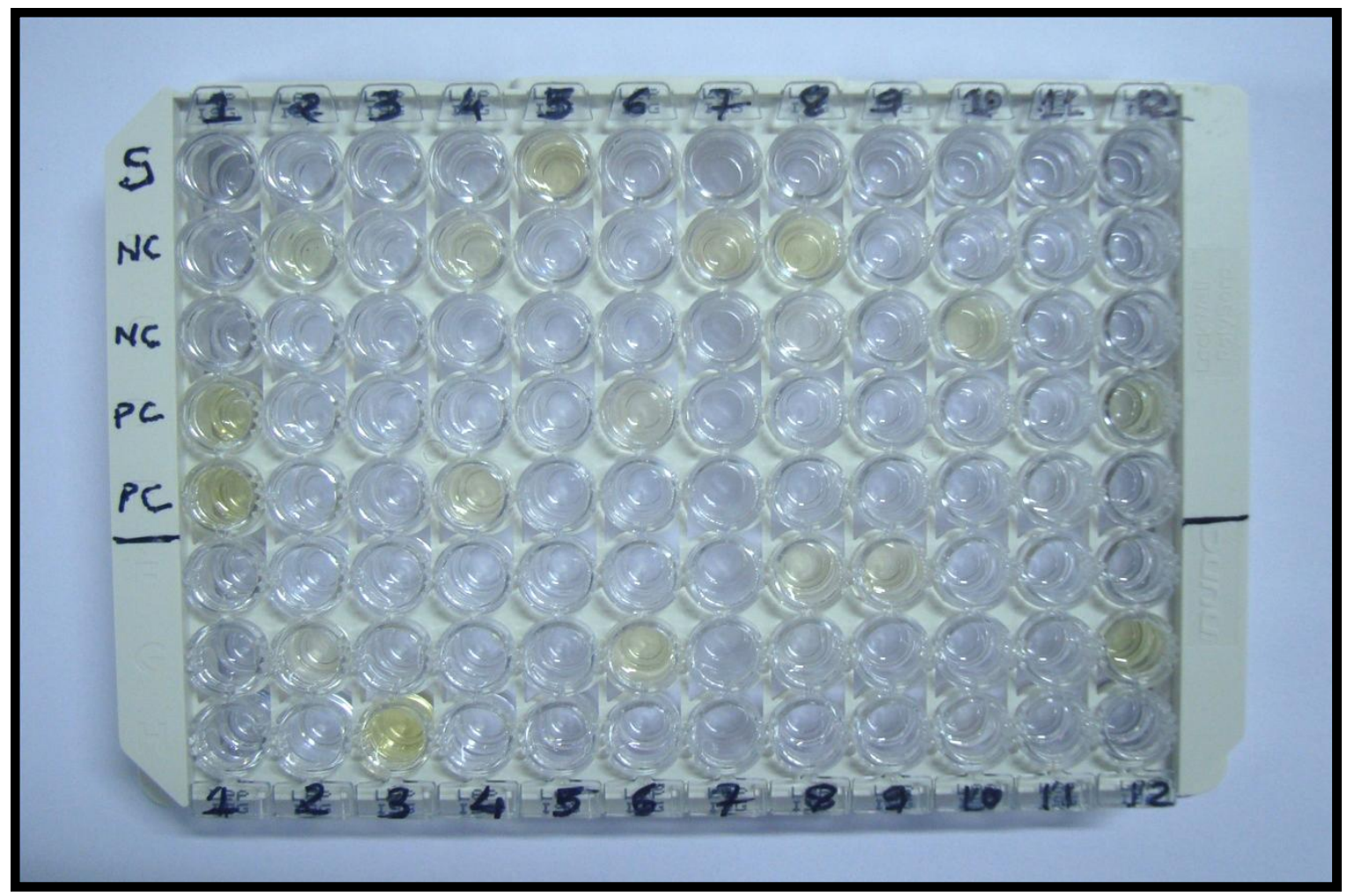

Sex-wise seroprevalence did not differ significantly $(\mathrm{P} \leq 0.05)$ in the study. This could possibly be due to number of sample tested from male and female cattle and supported the observations of Shafighi et al., (2010) who too did not observed any sex bias in respect of seropositivity against different leptospiral serovar. Age-wise seroprevalence also did not revealed significant difference between different age group of cattle. In the contrast of present findings Health and Johnson (1994) concluded that proportion of seropositivity of serovar hardjo increase with age of cattle.

Serovar hardjo is considered as host adapted serovar of cattle though in this study it was 
also reported in clinically ailing cattle having history of abortion, mastitis/agalactia/ oligolactia, repeat breeder and fever in different percent combination and supported the findings of Momtazand Moshkelani (2012) who too reported L. hardjo is a major pathogen causing bovine abortion in Iran. Further, Ellis et al., (1986) observed full range of clinical signs including abortion, mummification, still birth, premature birth/weak calf birth and also full term birth of live apparently healthy calves in experimental study of leptospiral serovar hardjo in cattle. So in L. hardjo infection, cattle remain apparently healthy or a range of clinical signs of reproductive/ systemic involvement in different combination.

\section{Acknowledgements}

Authors are thankful to the Dean and Principle, Vanbandhu College of Veterinary Sciences and A.H., Navasari Agricultural University, Eru cross road, Navsari, Gujarat, India for providing the necessary facilities to carry out this work.

\section{Conflict of interest statement}

Authors declare that they have no conflict of interest.

\section{References}

Adler, B. and Pena Moctezuma A.: Leptospira and leptospirosis. Vet Microbiol. 140(3-4): 287-296, 2010.

Agrawal, R, Kumar, M., Kumar, M. and Srivastava S.K. 2005.

Epidemiological pattern of leptospirosis in livestock of Uttaranchal state. Indian Journal of Comparative Microbiology, Immunology and Infectious Diseases. 26 (2):109-113.

Al-Badrawi, T.Y.G., Habasha, F.G., Sultan, S.H. 2010. Serological study of
Leptospirosis in catle, sheep and goats in Baghdad Province. Al- Anbar Journal Veterinary Science. 3:78-82.

Angeliki, R.B. 2010. Leptospirosis: an important zoonotic diseases. Current Research, Technology and Education Topics in Applied Microbiology and Microbial Biotechnology. A. Mendezvilas(Ed). 687-693.

Bahaman, A.R.; Ibrahim, A. L. and Adam, H. 1987. Serological prevalence of leptospiral infection in domestic animals in West Malaysia. Epidem. Inf. 99: 379-392.

Bahari, A., Abdollahpour, G., Sadeghi-Nasab, A., Sattari Tabrizi, S., Yavari, M. and Dadmehr, B.2011. A serological survey on leptospirosis in aborted dairy cattle in industrial farms of Hamedan suburb, Iran. Iranian Journal of Veterinary Research. 12(4): 337-339.

Balakrishnan, G., Roy, G. P., Govindarajan, R., Ramaswamy, V., and Murali Manohar, B.2011. Seroepidemiological studies on leptospirosis among bovines in organized farm. IJAVMS. 5(6): 511519.

Cárdenas- Marrufo,M.F., Vado-Solís, I., Pérez-Osorio, C.E. and Segura-Correa, J.C. 2011. Seropositivity to leptospirosis in domestic reservoirs and detection of leptospira spp. From water sources, in Farms of Yucatan, Mexico. Tropical and Subtropical Agroecosystems. 14: 185 - 189.

El Jalii, I.M. 2008. Comparison between ELISA and the Microscopic Agglutination Test for the Diagnosis of Bovine Leptospirosis. Revue Élev. Méd. vét. Pays trop., 61 (2): 73-75.

El Jalii, I.M. 2008. Comparison between ELISA and the Microscopic Agglutination Test for the Diagnosis of Bovine Leptospirosis. Revue Élev. Méd. vét. Pays trop. 61 (2): 73-75.

Hamali, H. Jafari Joozani, R. and 
Abdollahpour, G. R. (2012). Serodiagnosis and molecular survey on leptospiral abortions in the dairy cattle of Tabriz. Iranian Journal of Veterinary Research. 13(2):120-125.

Health, S.E., Johnson R (1994). Leptospirosis. J. Am. Vet. Med. Assoc. 205:15181523.

Jangam, A.K. and Wadekar, P.2012. Web Agri State Package. ICAR research complex for Goa.

Kocabiyik, A.L. and Cetin, C. (2004). Bovine leptospirosis in south Marmara region of Turkey: A serological survey. Revue Méd. Vét. 155 (12): 606-608.

Mandal, S., Joardar, S.N., Chakraborty, D and Sardar, N.2008. Seroepidemiological study of bovine leptospirosis in West Bengal. Indian J. Comp. Microbiol. Immunol. Infect. Dis. 29 (1\&2): 42-44.

Mineiro, A.L.B.B., Vieira, R.J., Costa, E.A.,Santos, R.L., Gonçalves, L.M.F., Carvalho, S.M., Bomfim, M.R.Q. and Costa, F.A.L. 2011. Serology, polymerase chain reaction and histopathology for leptospirosis in samples collected at slaughter from dairy cows of Parnaiba region, State of Piaul, Brazil. Pesq. Vet. Bras, 31(10):859-866.

Momtaz, $\mathrm{H}$ and Moshkelani, S.2012. Detection and characterization of Leptospira spp. isolated from aborted bovine clinical samples. Acta Vet. Brno,
81: 021-025. doi:10.2754/avb201281 010021

Radostits, O.M., Gay, C.C., Hinchcliff, K.W. and Constable, P.D. (2009). Veterinary Medicine, a text book of the diseases of cattle, horse, sheep, pigs, and goat. Saunders Elsevier. Pp: 1094-1105.

Radostits, O.M., Gay, C.C., Hinchcliff, K.W. and Constable, P.D. 2009. Veterinary Medicine, a text book of the diseases of cattle, horse, sheep, pigs, and goat. Saunders Elsevier. Pp: 1094-1105.

Sakhaee, E., Abdollahpour, Gh. R., Bolourchi, M., Hasani Tabatabayi, A. M.and Sattari Tabrizi, S. 2007. Serologic and bacteriologic diagnosis of bovine leptospirosis in Tehran suburb dairy farms. Iranian Journal of Veterinary Research. 8(4):325-332.

Savalia, C.V. 2001. Seroprevalence of Leptospirosis in bovines of Gujarat. The veterinarian. 25(2):4-5.

Shafighi,T., Abdollahpour, G., Zahraei Salehi, T. and Tadjbakhsh, H.2010. Serological and bacteriological study of leptospirosis in slaughtered cattle in north of Iran (Rasht). African Journal of Microbiology Research. 4(20): 21182121.

Songer, J. G.; Chilelli, C. J.; Marshall, M. M.; Noon, T. H. and Meyer, R. 1983. Serological survey for leptospirosis in Arizona beef cattle in 1981. Am. J. vet. Res. 44: 1763-1764.

\section{How to cite this article:}

Patel, J.M., M.C. Prasad, P.D. Vihol, I.H. Kalyani, M.G. Prajapati, H.C. Parmar, R.D. Varia and Patel, K.M. 2017. Seroprevalence of Leptospira hardjo in Cattle of Gujarat, India. Int.J.Curr.Microbiol.App.Sci. 6(11): 1304-1310. doi: https://doi.org/10.20546/ijcmas.2017.611.156 